\title{
CLIMATE RISK VULNERABILITY ASSESSMENT OF THE MAJOR CROPS IN THE PROVINCE OF AGUSAN DEL NORTE, PHILIPPINES
}

\author{
Arnold G. Apdohan ${ }^{1,2}$, Rowena P. Varela ${ }^{3}$, Raquel M. Balanay ${ }^{3}$ \\ ${ }^{1}$ College of Engineering and Geosciences, Caraga State University, Butuan City, Philippines - agapdohan@ carsu.edu.ph \\ ${ }^{2}$ Center for Resource Assessment, Analytics and Emerging Technologies, Caraga State University, Butuan City, Philippines \\ ${ }^{3}$ College of Agriculture and Agri-Industries, Caraga State University, Butuan City, Philippines
}

KEY WORDS: Climate Risk Vulnerability, GIS, MaxEnt, Sensitivity, Exposure, Adaptive Capacity.

\begin{abstract}
:
Assessing an area's vulnerability can serve as an effective planning tool to increase resilience to climate-related hazards. This paper provides information on the most vulnerable municipalities to climate change impacts in the province of Agusan del Norte, Philippines. The assessment included in the geospatial analysis were physical, agro-ecological, and socio-economic indicators clustered under the components of exposure, sensitivity, and adaptive capacity. Using MaxEnt, modelling the suitability of crops due to changes in temperature and precipitation by the year 2050 determines the crops' sensitivity. A combination of natural hazards datasets was used to estimate the extent of exposure to each municipality within the province under pressure from climate and hydro-meteorological risks. An up-to-date database from the concerned local government units for adaptive capacity indicators was clustered into seven capitals: economic, natural, human, physical, social, anticipatory, and institutional. The total CRV model for rice, corn, and banana crops revealed that the municipalities identified as highly vulnerable due to their high exposure to climate hazards, the decreasing crops' suitability to climate variability, and low adaptive capacity.
\end{abstract}

\section{INTRODUCTION}

Impacts of climate change on food production systems depend primarily on the adaptation measures undertaken by local communities (International Center for Climate Change Governance, 2016). These adaptation strategies will also apply to the complex issues on water use and food production as affected by climate change. The lack of adaptive capacities of the farmers to cope with such climatic variability increases its level of drought vulnerability. Vulnerability to climate change is defined as "the degree to which a system is susceptible to and unable to cope with, adverse effects of climate change, including climate variability and extremes. Vulnerability is a function of the character, magnitude, and rate of climate change and variation to which a system is exposed, its sensitivity, and adaptive capacity (IPCC, 2007).

In the Philippines, due to its geographical and environmental setting, it has become extremely vulnerable to natural disasters, including climate change (Senate Economic Planning Office, 2013). SEPO (2013) quoted that "The Philippines is one of the most hazard-prone countries in the world". Climate change is already impacting the country, threatening to weaken the development prospects and worsen the vulnerability of our poorer populations. With projected changes in precipitation, temperature, and the intensity of tropical cyclones, the country will need to put in a lot of effort to prepare for the effects of climate change on the various climate-sensitive sectors (PAGASA, 2011). In addition, extreme weather events such as typhoons, drought, heavy rains regularly visit the country, and many have led to disasters costing the country billions in pesos every. The country's agri-fisheries sector is a perennial casualty of these climate-related risks. From 2010 to 2014, loss and damages from climate/weather-induced disasters reached a total of Php136 billion or an average of PhP27 billion annually (Field
Programs Operational Planning Division - Department of Agriculture, 2015). The increased vulnerability of agri-fisheries communities to climate risks poses a key challenge in enabling them to pursue more resilient and productive livelihoods and ultimately rise out of poverty. At the regional scale, it has been reported during 2011-2015, the north-eastern Mindanao region (Caraga) was hit by typhoons that caused tremendous agricultural damage. Typhoons Sendong, Agaton, Pablo, and Senyang have been the most publicized ones that brought disasters to the region. In 2012, Typhoon Pablo caused an estimated PHP 3.6 B damaged in agriculture in Regions 4b, 6, 7, 10, 1112 and Caraga (National Disaster Risk Reduction and Management Council, 2012).

In response, the Department of Agriculture (DA) launched the Adaptation and Mitigation Initiative in Agriculture (AMIA) in 2014, with an overall vision of a Philippine agri-fisheries sector that enables local communities to manage climate risks while pursuing sustainable livelihoods. As its overall approach, AMIA develops and promotes climate-resilient agriculture (CRA) through implementing technologies and practices, introducing institutional and social innovations, and accessing climaterelevant support services.

Climate Risk Vulnerability Assessment (CRVA) of AMIA is conducted to guide the AMIA targeting and planning for building the climate-resilient agri-fisheries communities. It determines the impacts of climate change to have complementary plans and implement strategies to support local communities in managing climate-related risks. It also seeks to introduce complementary activities for building appropriate climate-responsive financial and other key support services. Hence, this paper assessed the climate risk vulnerability status in a geospatial landscape at the provincial level by integrating field data and secondary data clustered under the three components in measuring vulnerability such as sensitivity, exposure, and adaptive capacity using GIS

Corresponding author 
techniques and Maxent software. Outputs of CRVA serve as the basis for developing CRA-related decision-support tools, preliminary models for community action research, and recommended guidelines for providing climate information services.

\section{METHODOLOGY}

\subsection{Study Area}

Agusan del Norte (Figure 1) is a province in the Caraga region located in the northeastern part of Mindanao. It is bounded by Butuan Bay and Surigao del Norte on the north, Surigao del Sur on the east, Misamis Oriental on the west and Agusan del Sur on the South. The province has a total land area of 2,730.24 square kilometers, reaching 3,546.86 square kilometers. Of the total land area (excluding Butuan City), $72.96 \%$ is forestland, while $25.43 \%$ is for agriculture, which is the primary source of income of the province. Only $1.62 \%$ are considered built-up areas used for settlement, Special Economic Zones, and infrastructure and utilities (Parel, Detros, \& Salinas, 2015).

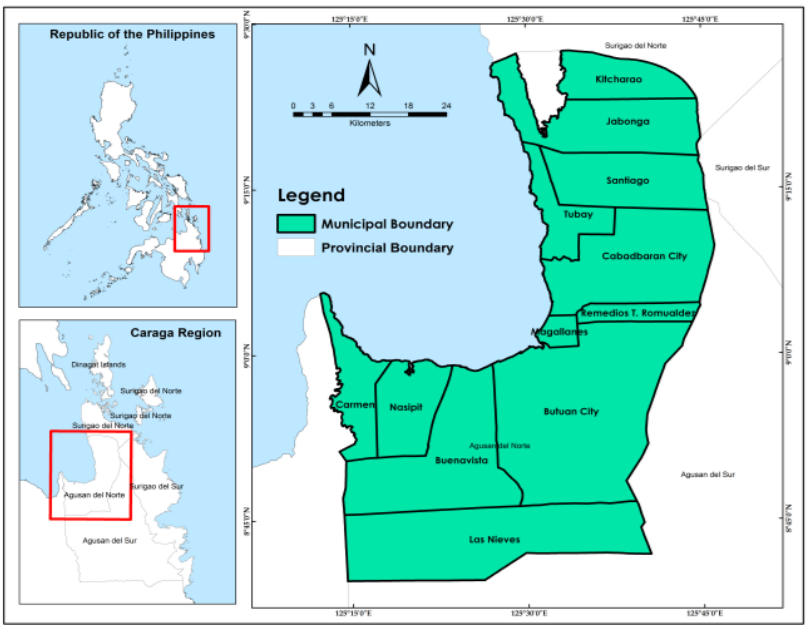

Figure 1. The Study Area: Agusan del Norte, Philippines.

\subsection{CRVA Framework}

The harmonized CRVA framework was adapted from the Centro Internacional de Agricultura Tropical (CIAT) Southeast Asia the lead partner agency of the AMIA program. The sensitivity analysis assumed of a high emission scenario by 2050 whereas the adaptive capacity component was derived from the up-to-date available data from the respective local government units of the province. The detailed composition of each component is shown in Figure 2. The resulting vulnerability assessment enables evidence-based spatial targeting of agricultural extension and financial investment in areas most at risk or tailored to a specific hazard crop or lack of adaptive capacity (Palao et al., 2016).

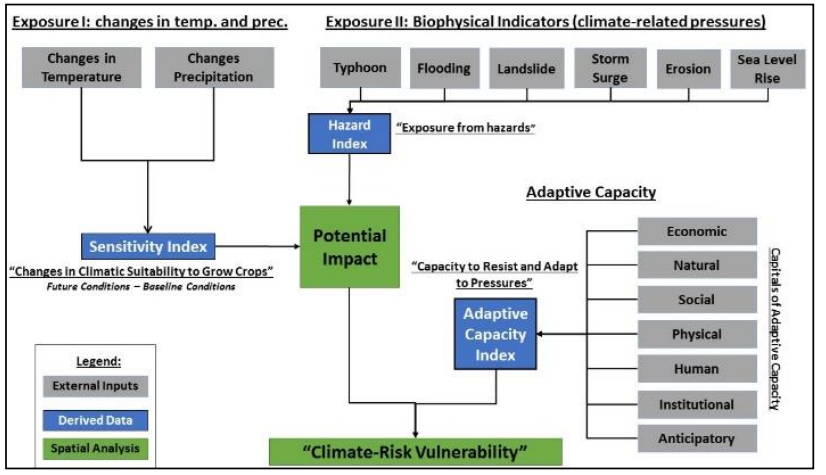

Figure 2. CRVA Framework.

2.2.1 Crop Sensitivity: The crop sensitivity was assessed by changes in climatic suitability of crops by the year 2050 vis-à-vis the baseline (current) year. The Maximum Entropy (Maxent) model was used to model crop suitability under climate change. Analyzing changes in crop suitability involves a two-step process. The first step is to assess the baseline crop suitability based on the condition that a species is predicted to occur at a particular location if it approximately matches the environmental condition where it is observed. The second step is to predict the location of a species on a particular time slice if it matches the environmental condition where it is observed in the baseline condition.

The WordClim dataset was used for baseline and future conditions (Table 1). The bioclimatic variables are derived from monthly temperature and rainfall values and were processed to generate more biologically meaningful climate variables (Hijmans, Cameron, Jones, \& Jarvis, 2005). The described bioclimatic factors are relevant to understand species responses to climate change (O'Donnell \& Ignizio, 2012). The processed Global Circulation Models (GCMs) of baseline and future (2050) were from CIAT.

\begin{tabular}{|c|c|c|}
\hline \multicolumn{2}{|r|}{ Bioclimatic Parameters } & Symbology \\
\hline \multirow{11}{*}{ 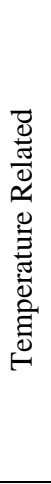 } & Annual mean temperature & Bio_1 \\
\hline & Mean diurnal range & Bio_2 \\
\hline & Isothermality & Bio_3 \\
\hline & Temperature seasonality & Bio_4 \\
\hline & $\begin{array}{l}\text { Maximum temperature of warmest } \\
\text { month }\end{array}$ & Bio_5 \\
\hline & $\begin{array}{l}\text { Minimum temperature of coldest } \\
\text { month }\end{array}$ & Bio_6 \\
\hline & Temperature annual range & Bio_7 \\
\hline & Mean temperature of wettest quarter & Bio_8 \\
\hline & Mean temperature of driest quarter & Bio_9 \\
\hline & Mean temperature of warmest quarter & Bio_10 \\
\hline & Mean temperature of coldest quarter & Bio_11 \\
\hline \multirow{9}{*}{ 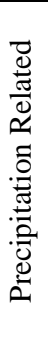 } & Annual precipitation & Bio_12 \\
\hline & Precipitation of wettest month & Bio_13 \\
\hline & Precipitation of driest month & Bio_14 \\
\hline & Precipitation seasonality & Bio_15 \\
\hline & Precipitation of wettest quarter & Bio_16 \\
\hline & Precipitation of driest quarter & Bio_17 \\
\hline & Precipitation of warmest quarter & Bio_18 \\
\hline & Precipitation of coldest quarter & Bio_19 \\
\hline & Number of consecutive dry days & Bio_20 \\
\hline
\end{tabular}

Table 1. Bioclimatic variables used in crop distribution modeling. 
Maxent model is a species or crop distribution model commonly used to estimate the most suitable areas for a species or crop based on probability in geographic areas where the distribution of crops is scarce. Climate change suitability of crops by the year 2050 vis-à-vis the baseline (current) condition were simulated to assess the sensitivity of the crop. The difference (expressed as a percentage) in future and baseline suitability determines the climate change crop suitability and reflects the degree of crop sensitivity to changing environmental conditions. A more remarkable change in a negative direction reflects a higher impact of climate change. An index was developed from -1.0 to 1.0 for CRVA. An index range from 0.25 to 1.0 indicates a loss in suitability, while -0.25 to -1.0 indicates a gain in suitability (Palao et al., 2016) as shown in Table 2.

\begin{tabular}{|l|c|c|}
\hline $\begin{array}{c}\text { Percent Change in } \\
\text { Suitability } \\
\text { (Range in \%) }\end{array}$ & Index & Description \\
\hline$\leq-50$ (Very high loss) & 1.0 & Loss \\
\hline$>-50 \leq-25$ (High loss) & 0.5 & \\
\hline$>-25 \leq-5$ (Moderate loss) & 0.25 & \\
\hline$>-5 \leq 5$ (No change) & 0 & No Change \\
\hline$>5 \leq 25$ (Moderate gain) & -0.25 & Gain \\
\hline$>25 \leq 50$ (High gain) & -0.5 & \\
\hline$>50$ (Very high gain) & -1.0 & \\
\hline
\end{tabular}

Table 2. Sensitivity index based on percent change in crop suitability from baseline to future condition.

2.2.2 Hazards: A combination of natural hazards datasets was used to estimate the extent of exposure to each municipality within the province of Agusan del Norte under pressure from climate and hydro-meteorological risks. The development of a hazard index relies on spatial analysis of the weighted combination of different historical climate-related natural hazards (Table 3). At least six hazards were identified in the province of Agusan del Norte. These are tropical cyclone, flooding, landslide, storm surge, erosion and sea-level rise. The selection of hazards has validated during the consultation with the local government unit partners.

\begin{tabular}{|c|c|c|}
\hline Parameter & Source & $\begin{array}{c}\text { Unit of } \\
\text { measurement, spatial } \\
\text { and temporal } \\
\text { resolution }\end{array}$ \\
\hline $\begin{array}{l}\text { Tropical } \\
\text { Cyclone }\end{array}$ & $\begin{array}{l}\text { UNEP/UNISDR, } \\
2013\end{array}$ & $\begin{array}{l}1 \text { kilometer pixel } \\
\text { resolution. Estimate } \\
\text { of tropical cyclone } \\
\text { frequency based on } \\
\text { Saffir-Simpson scale } \\
\text { category } 5 \text { (> } 252 \\
\mathrm{~km} / \mathrm{h} \text { ) from year } \\
1970 \text { to } 2009 \text {. }\end{array}$ \\
\hline Flooding & $\begin{array}{l}\text { AMIA multi- } \\
\text { hazard map / } \\
\text { baseline data from } \\
\text { Mines and } \\
\text { Geosciences } \\
\text { Bureau, } \\
\text { Department of } \\
\text { Environment and } \\
\text { Natural Resources } \\
\text { (MGB, DENR) }\end{array}$ & $\begin{array}{l}\text { 1:10,000 scale. } \\
\text { Susceptibility of } \\
\text { flood risk for } \\
\text { Philippines }\end{array}$ \\
\hline Erosion & $\begin{array}{l}\text { AMIA multi- } \\
\text { hazard map / } \\
\text { baseline data from }\end{array}$ & $\begin{array}{l}1: 10,000 \text { scale. Soil } \\
\text { erosion classified }\end{array}$ \\
\hline
\end{tabular}

\begin{tabular}{|c|c|c|}
\hline & $\begin{array}{l}\text { Bureau of Soils and } \\
\text { Water Management }\end{array}$ & $\begin{array}{l}\text { from low to high } \\
\text { susceptibility }\end{array}$ \\
\hline Landslide & $\begin{array}{l}\text { AMIA multi- } \\
\text { hazard maps / } \\
\text { baseline data from } \\
\text { MGB, DENR }\end{array}$ & $\begin{array}{l}\text { 1:10,000 scale. } \\
\text { Landslide classified } \\
\text { from low to high } \\
\text { susceptibility }\end{array}$ \\
\hline Storm Surge & $\begin{array}{l}\text { AMIA multi- } \\
\text { hazard maps / } \\
\text { baseline data from } \\
\text { Disaster Risk and } \\
\text { Exposure } \\
\text { Assessment for } \\
\text { Mitigation, } \\
\text { Department of } \\
\text { Science and } \\
\text { Technology } \\
\text { (DREAM, DOST) }\end{array}$ & 1:10,000 scale. \\
\hline $\begin{array}{ll}\text { Sea } & \text { Level } \\
\text { Rise } & \end{array}$ & $\begin{array}{l}\text { AMIA multi- } \\
\text { hazard map }\end{array}$ & $\begin{array}{l}\text { Assumption based } \\
\text { on } 5 \mathrm{~m} \text { sea level rise }\end{array}$ \\
\hline
\end{tabular}

Table 3. Hazards datasets used for exposure component.

The experts identified the hazard weights used in this study through focus group discussions of SUCs, national government agencies, and other stakeholders organized by the lead partner from CIAT. The experts were asked to score ( 1 is low and 5 is high probability/impact) hazard risk based on the qualitative assessment using the following criteria, (a) Probability of occurrence, (b) Impact of local household income, (c) Impact on key natural resources to sustain productivity (refers to how key resources such as water quality and quantity, soil fertility, and biodiversity are affected) (d) Impact on food security of the country (e) Impact on the national economy.

Table 4 summarizes the hazards weight distribution in the province. The criteria used also reflect the impact of hazards at different scales from local, landscape, and national levels. A spatially weighted sum was used to develop the hazards index level in the province. For each municipality in the province, the value of the hazard index was computed and normalized using equation 1 .

$$
\text { Haz_norm }=\left(\mathrm{X}-\mathrm{X}_{\min }\right) /\left(\mathrm{X}_{\max }-\mathrm{X}_{\min }\right)
$$

where: Haz_norm $=$ is the normalized values of the hazard index

$\mathrm{X}=$ is the original value of the indicator of the municipality

$\mathrm{X}_{\max }=$ is the highest value among all the municipalities

$\mathrm{X}_{\min }=$ is the lowest value among all municipalities

There were five equal breaks used to geo-visualize the map and were classified into 0-0.20 (Very Low), 0.20-0.40 (Low), 0.400.60 (Moderate), 0.60-0.80 (High), and 0.80-1.0 (Very High).

\begin{tabular}{|l|c|}
\hline \multicolumn{1}{|c|}{ Hazards } & Weights (\%) \\
\hline Typhoon & 16.95 \\
\hline Flood & 15.25 \\
\hline Drought & 16.95 \\
\hline Erosion & 12.71 \\
\hline Landslide & 14.41 \\
\hline Storm Surge & 8.47 \\
\hline Sea Level Rise & 5.08 \\
\hline Salt Water Intrusion & 10.17 \\
\hline
\end{tabular}

Table 4. Hazard weights used in the province of Agusan del Norte. 
2.2.3 Adaptive Capacity: In this study, the AC indicators were clustered into seven (7) capitals, these are economic, natural, human, physical, social, health, anticipatory, and institutional. The project employed the indicators suggested by the Department of Agriculture - Regional Field Office, Caraga as shown in Table 5. For each municipality in the province, the value of the hazard index was computed and normalized using equation 2 .

$$
\mathrm{AC}_{\text {indicator_norm }}=\left(\mathrm{X}-\mathrm{X}_{\min }\right) /\left(\mathrm{X}_{\max }-\mathrm{X}_{\min }\right)
$$

where: $\mathrm{AC}_{\text {indicator_norm }}=$ is the normalized values of the $\mathrm{AC}$ indicators

$\mathrm{X}=$ is the original value of the indicator of the municipality
$\mathrm{X}_{\max }=$ is the highest value among all the municipalities $\mathrm{X}_{\min }=$ is the lowest value among all the municipalities

The composite index for each capital was constructed by getting the average of all indicators (Table 5). After computing for the composite index, the values were normalized again for consistency. The composite $\mathrm{AC}$ is derived using the sum function of all capital indices. The AC index result was then inverted, where 1.0 was considered as low AC. Each of the indicators was normalized and treated with equal weights. Five equal breaks were developed to establish the thresholds: 0-0.20 (Very Low), 0.20-0.40 (Low), 0.40-0.60 (Moderate), 0.60-0.80 (High), and 0.80-1.00 (Very High).

\begin{tabular}{|c|c|c|c|c|c|c|}
\hline Economic & Natural & Human & Physical & Social & Anticipatory & Institutional \\
\hline $\begin{array}{l}\text { - Poverty } \\
\text { incidence } \\
\text { - Inflation rate } \\
\text { - Ag. min. wage } \\
\text { - Total banks } \\
\text { and financial } \\
\text { institutions } \\
\text { - Number of } \\
\text { finance } \\
\text { cooperatives } \\
\text { - Employment } \\
\text { in agriculture } \\
\text { - \% of farmers } \\
\text { covered by } \\
\text { crop insurance } \\
\text { - Price of diesel } \\
\text { - Cost of } \\
\text { electricity }\end{array}$ & $\begin{array}{l}\text { - \% of crops } \\
\text { irrigated } \\
\text { - \% of forest } \\
\text { and } \\
\text { mangroves } \\
\text { - Agricultural } \\
\text { production } \\
\text { area } \\
\text { - Presence of } \\
\text { irrigation }\end{array}$ & $\begin{array}{l}\text { - Number of private } \\
\text { and public } \\
\text { secondary, tertiary, } \\
\text { and tech. } \\
\text { vocational schools } \\
\text { - Ratio of public } \\
\text { school teachers to } \\
\text { students } \\
\text { - Literacy rate } \\
\text { - Public and private } \\
\text { health services } \\
\text { - Number of public } \\
\text { and private doctors } \\
\text { - Health services } \\
\text { manpower } \\
\text { - Number of local } \\
\text { citizens with } \\
\text { PhilHealth } \\
\text { - \% prevalence rate } \\
\text { of malnourished } \\
\text { children under 7yo } \\
\text { - Age dependency } \\
\text { ratio }\end{array}$ & $\begin{array}{l}\text { - Infrastructure } \\
\text { investment } \\
\text { - Infrastructure } \\
\text { network } \\
\text { - \% of } \\
\text { households } \\
\text { with access to } \\
\text { water services } \\
\text { - \% of } \\
\text { households } \\
\text { with access to } \\
\text { electricity } \\
\text { services } \\
\text { - Number of } \\
\text { public } \\
\text { transport } \\
\text { - Average farm } \\
\text { size } \\
\text { - Number of } \\
\text { farm } \\
\text { equipment/pos } \\
\text { tharvest } \\
\text { - Number of } \\
\text { seed growers }\end{array}$ & $\begin{array}{l}\text { - \% of women } \\
\text { in } \\
\text { government } \\
\text { - Number of } \\
\text { registered } \\
\text { farmer } \\
\text { groups or } \\
\text { unions } \\
\text { - \% of farmers } \\
\text { who are } \\
\text { member of } \\
\text { registered } \\
\text { unions/grou } \\
\text { ps/coops }\end{array}$ & $\begin{array}{l}\text { - No. of } \\
\text { weather } \\
\text { stations } \\
\text { - Early } \\
\text { warning } \\
\text { system } \\
\text { - Access to } \\
\text { communicat } \\
\text { ion } \\
\text { technology }\end{array}$ & $\begin{array}{l}\text { - Number } \\
\text { of } \\
\text { agricultur } \\
\text { al staff } \\
\text { - Number } \\
\text { of farmers } \\
\text { visited or } \\
\text { consulted } \\
\text { with agri- } \\
\text { extension } \\
\text { workers/st } \\
\text { aff }\end{array}$ \\
\hline
\end{tabular}

Table 5. List of indicators used in measuring adaptive capacity.

2.3.4 CRVA Index Using GIS: The normalized component indicators were integrated using the concept of vulnerability. Adapting the framework from CIAT, the total vulnerability in the province of Agusan del Norte was calculated using Equation 3.

$$
\mathrm{CRVA}=\left[\left(0.15^{*} \mathrm{~S}\right)+\left(0.15^{*} \mathrm{E}\right)+\left(0.70^{*} \mathrm{AC}\right)\right.
$$

where CRVA $=$ is the total climate risk vulnerability of the municipality

$\mathrm{S}=$ is the sensitivity of the municipality

$\mathrm{E}=$ is the sensitivity of the municipality

$\mathrm{AC}=$ is the adaptive capacity of the municipality

\section{RESULTS AND DISCUSSION}

\subsection{Sensitivity Index}

Figure 3 shows the changes in climatic suitability of the priority crops in the provinces of Agusan del Norte for rice, corn, and banana crops through climate modeling and use of species distribution model. Several areas significantly decrease climate suitability for rice crop while some have maintained their suitability, as shown in Figure 3a.
The suitability in the central part of the province, particularly in Butuan City, Buenavista, and Carmen, revealed that a high adverse impact on climate suitability in the future is manifested. In contrast, the rest of the municipalities of the province have gained or maintained their suitability.

On the other hand, Figure $3 b$ shows that the suitability of corn crop where the entire municipalities of the province except Magallanes are affected by the adverse impact (loss in suitability) in the coming years. It is misleading to conclude that crops in geographic areas that will experience a decrease in climate suitability will not survive. However, a reduction in yield is expected in high-impacted areas. Since climate cannot control, an improved crop production or farming practices system that promotes healthy soil and efficient water use are vital as a means of climate change (Palao et al., 2016). The result emphasizes the need for improvement in crop management, better provision and optimized utilization of the water for irrigation, and increased adaptation strategies to cope with such increasing climatic pressures that affect agricultural productivity. Figure $3 \mathrm{c}$ shows that the banana crop is favorable in all municipalities both have gained and maintained its suitability. 


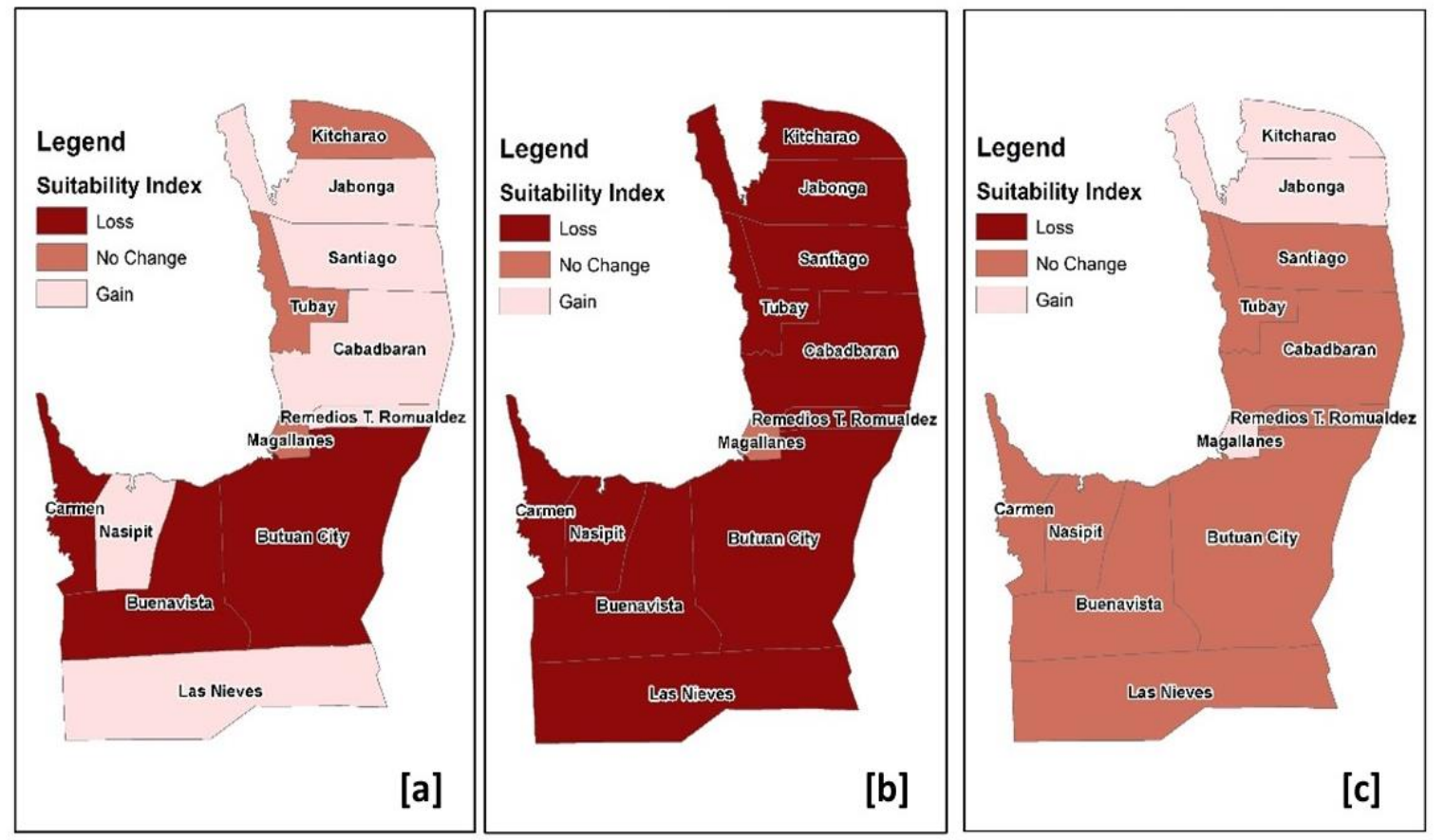

Figure 3. Sensitivity (suitability) index of Rice [a], Corn [b], and Banana [c] in Agusan del Norte.

\subsection{Hazard Index}

Figure 4 shows the degree of exposure to hazards across municipalities of Agusan del Norte. The northern part of the province has a high incidence of tropical cyclone compared to other municipalities located in the southern part. Higher exposure incidence to sea level and storm surge are also observed in Butuan City since this area sits below sea level.

On the other hand, the municipality of Jabonga belonged to most exposed to flooding based on the geographical setting since this area is the main outlet of Mainit lake, where all of the river water tributaries in the adjacent municipalities empty into this area that will cause significant overflow of the lake. High elevated areas are observed to be high exposure to landslide and erosion.

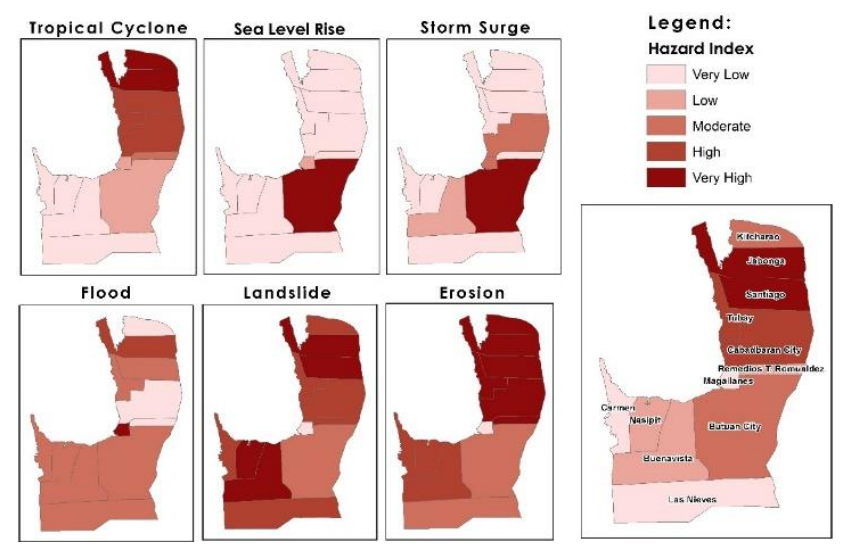

Figure 4. Hazard index map in Agusan del Norte.

Overall exposure results showed that a higher incidence of hazards in the municipalities of Jabonga and Santiago are observed in the province. The analysis was based on the number of pixels counts, which shows each municipality's spatial coverage of hazards.

\subsection{Adaptive Capacity Index}

The adaptation process requires learning from previous experiences to cope with the current climate and apply these lessons to cope with future climate, including surprises. The AC indicators were clustered into seven (7) capitals such as economic, natural, human, physical, social, anticipatory, and institutional.

Figure 5 presents the results of the spatial analysis of all capitals and the aggregated overall adaptive capacity index. The result shows that Butuan City is the most adaptive municipality within the province regarding economic, natural, social, human, physical, anticipatory, and institutional (Figure 5). The municipality has high coping mechanisms or strategies to respond the climate-related hazards. However, most municipalities across the study sites have a very low AC index in terms of human capital based on the indicators considered (Table $5)$.

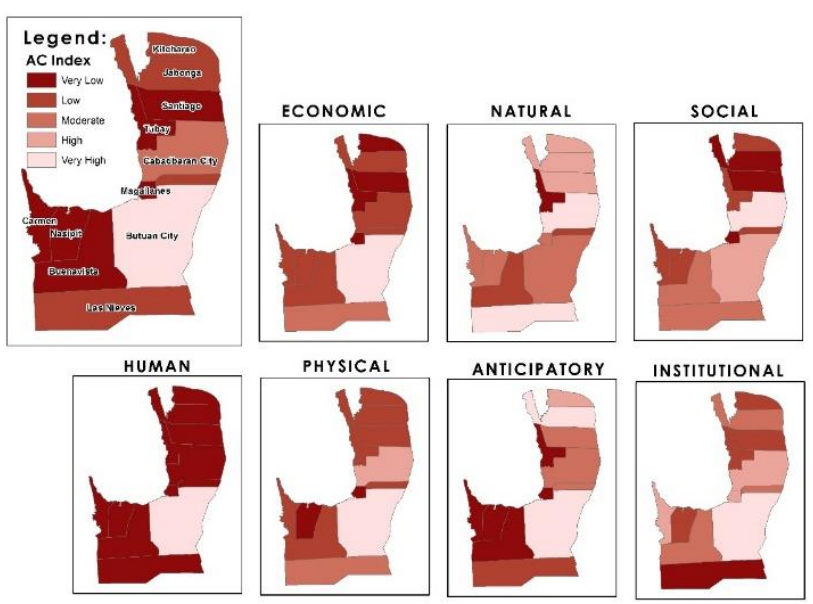

Figure 5. Adaptive Capacity index in Agusan del Sur. 
The overall capacity index shows that 9 out of 12 or $75 \%$ of the municipalities have a low adaptive capacity index. The results can be used by the local government units (LGUs) to improve their coping mechanisms by adding or increasing their services and interventions in the respective communities affected by climatic pressures.

\subsection{Total CRVA}

The vulnerability model was constructed using the GIS platform to pre-process the spatial datasets for the three components such as sensitivity, exposure, and adaptive capacity. The potential impact (sensitivity + exposure) in the respective municipalities showed the variations on how the commodities in these areas are exposed and adversely affected by climate change and hazards pressures in the coming years.

The total CRV for rice and banana crops (Figure 6a and Figure 6b) shows that municipalities were identified as highly vulnerable are Tubay, Santiago, Magallanes, Buenavista, Nasipit, and Carmen due to high potential impact (sensitivity and exposure) but low adaptive capacity. Likewise, the map shows that the rice and banana crops have the same index classification level. However, this is attributed to the same level of exposure and adaptive capacity index but differs from the climate suitability (sensitivity), as discussed in the previous section. On the other hand, the CRV result for corn shows that high vulnerability in most municipalities due to divergence of high exposure to hazards, lower climate suitability of crop in the future, and low adaptive capacity.

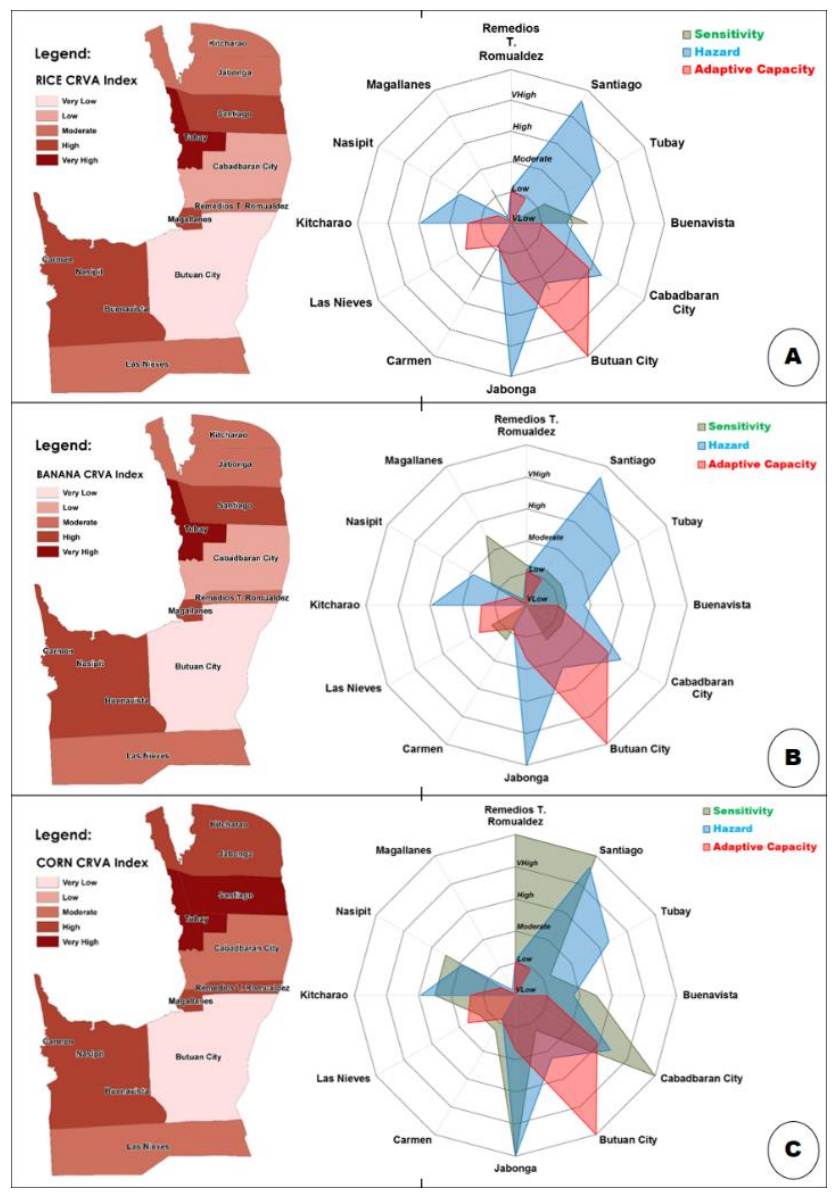

Figure 6. Total CRVA index map for rice (a), banana (b), and corn (c) in Agusan del Norte.
The radar graph shown in Figure 6 indicates that the intensities of the component drivers impacted the level of vulnerability of each municipality. Municipalities that showed low climate suitability of the crops is expected a reduction in yield due to the unfavorable climate condition in the coming years. The generated CRV maps were validated through consultation to the concerned local government units.

\section{CONCLUDING REMARKS}

The maps of climate risks generated through this study have been made available for the Province of Agusan del Norte as the basis for CRA investment planning. The maps on sensitivity, hazard, and adaptive capacity will be useful inputs in investment planning for agriculture for adaptation to climate change. Based on the CRV maps result, municipalities of Tubay, Santiago, Magallanes, Buenavista, Nasipit, and Carmen are among the highly vulnerable areas across three commodities due to their high exposure to hazards, decreasing suitability of crops to climate variability, and low adaptive capacity. Considering other factors are constant, investing in rice, banana, and corn in these vulnerable areas will be less favorable in the future. However, such potential impacts could be negated if the local government units continue investing in climate-change related programs and interventions that will improve farming practices and facilitate agri-related coping mechanisms and strategies. The output of this analysis will be helpful to policy-makers and stakeholders in better targeting programs and interventions towards adaptation measures in the province of Agusan del Norte.

\section{ACKNOWLEDGEMENT}

This research is an output of various organizations and individuals that share a common goal of addressing the threats of climate change to the agriculture sector in the Caraga Region. Bureau of Agricultural Research of the Department of Agriculture (DA-BAR) for the financial support to undertake the research. The Centro Internacional de Agricultura Tropical (CIAT) - Southeast Asia for the training and guidance in the conduct of this research. Caraga State University for giving time release to the faculty members to implement the project. The Department of Agriculture - Regional Field Office 13 for extending its valuable support in all aspects of the project implementation and the municipal agricultural Offices of the various towns of Agusan del Norte for unselfishly sharing their information aligned to climate change.

\section{REFERENCES}

Field Programs Operational Planning Division - Department of Agriculture, (2015).

Hijmans, R. K., Cameron, J. L., Jones, P. G., \& Jarvis, A., (2005). Very high recolution interpolated climate surfaces for global land areas. International Journal of Climitology, 1965-1978.

Internatioal Center for Climate Change Governance, (2016). The Best Climate Pratices. Retrieved from http://www.bestclimatepractices.org/how-does-climate-changeaffect-water-and-agriculture/

IPCC, (2007). Climate Change 2007: Impacts, Adaptation and Vulnerability.

National Disaster Risk Reduction and Management Council, 
(2012). Situation report on the effects of typhoon pablo.

O’Donnell, M. S., \& Ignizio, D. A., (2012). Bioclimatic Predictors for Supporting Ecological Applications in the Conterminous United States. U.S Geological Survey Data Series $691,10$.

PAGASA, (2011). Annual Report 2011, 1-68.

Palao, L. C. M., Guerten, N., Martinez, A., Parker, L., Balanza, J. G., Leyte, J., Burra, D. D., (2016). A climate risk vulnerability assessment for the adaptation and mitigation initiative in agriculture program in the philippines.

Parel, D. K. C., Detros, K. C., \& Salinas, C. M. G. R, (2015). Bottom-up Budgeting Process Assessment: Agusan del Norte. Philippine Institute doe Development Studies, Makati, Philippines.

Senate Economic Planning Office, (2013). Natiural Disaster at a Glance. $\quad$ Retrieved from https://www.senate.gov.ph/publications/AAG 2013-04 - Natural Disasters_final.pdf 